\title{
The Investigation of Social Studies Teacher Candidates Cognitive Flexibility Levels and Metacogniyive Learning Strategies in Terms of Different Variables
}

\section{Melek Körükcü}

Niğde Ömer Halisdemir University, Turkey.

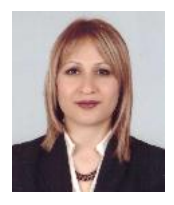

\begin{abstract}
The purpose of this research; social studies is to examine the relationship between the cognitive flexibility skills of teacher candidates and the learning strategies of supernatural (metacognitive learning strategies) in terms of various variables. The working (study) group of the research, who participated in the study on voluntary basis, is composed of a total of 150 social science teacher candidates; 94 female and 56 male ones who continue their education in the Department of Social Sciences Education at the Faculty of Education at a state university in Central Anatolia. and participate in volunteer work. "Cognitive Flexibility Scale" and "Bilingual Metacognitive Learning Strategies Identification Scale" were used as data collection tools in the research. Relational search screening model was used in the study. The data were analysed using the SPSS 20 program. According to the findings; it was determined found that the levels of cognitive flexibility levels of the social science teacher candidates were are moderate (in part agreeing partly agree) while metacognitive learning strategies identification levels were high.to determine the supra-learning strategies. It is concluded that the metacognitive learning strategies identification levels of female teacher candidates determination of supra-learning strategies are higher than those of male teacher candidates. On the other hand, it has been determined that there is no relationship between cognitive flexibility levels of social science teacher candidates and sex change gender.
\end{abstract}

Keywords: Cognitive flexibility, Metacognitive learning, Social studies teacher candidate, Social studies education, Learning, Cognitive.

Citation | Melek Körükcü (2020). The Investigation of Social Studies Teacher Candidates Cognitive Flexibility Levels and Metacogniyive Learning Strategies in Terms of Different Variables. Asian Journal of Education and Training, 6(1): 1-11.

History:

Received: 30 September 2019

Revised: 28 October 2019

Accepted: 6 December 2019

Published: 8 January 2020

Licensed: This work is licensed under a Creative Commons

Attribution 3.0 License (cc)

Publisher: Asian Online Journal Publishing Group
Funding: This study received no specific financial support

Competing Interests: The author declares that there are no conflicts of interests regarding the publication of this paper.

Transparency: The author confirms that the manuscript is an honest, accurate, and transparent account of the study was reported; that no vital features of the study have been omitted; and that any discrepancies from the study as planned have been explained.

Ethical: This study follows all ethical practices during writing.

\section{Contents}

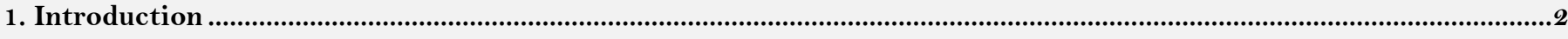

2. Method

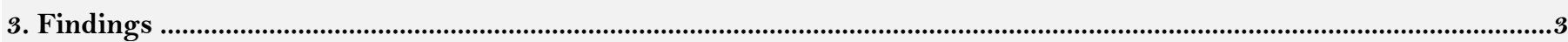

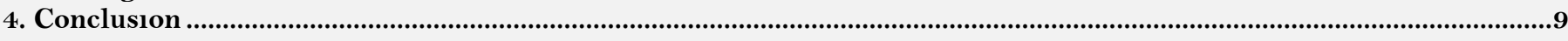

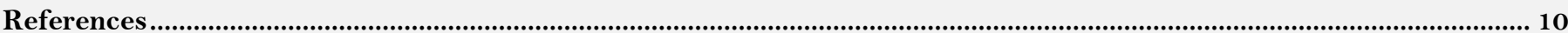




\section{Contribution of this paper to the literature}

This study contributes to the existing literature by examining the relationship between the cognitive flexibility skills of teacher candidates and the learning strategies of supernatural (metacognitive learning strategies) in terms of various variables.

\section{Introduction}

The effort to understand how an individual's mind works has still been on the agenda of human beings since the antiquity. In today's world, in which we experience the information age, there exists a fast and constant change which has never been experienced throughout history. With these changes, the expectations and qualifications required from the individuals by society have also changed. Modern educational approaches often underline the necessity for students to be active in learning process and put the emphasis on how knowledge should be learned rather than memorizing it. In this case, it's no doubt that teachers have the most important role. It can be considered a prerequisite that teachers should be highly-qualified for such changes.

Cognition is defined as the process of referring to previous knowledge, experience, etc. during knowledge acquisition. In fact, the processes of getting information about the world, understanding the world with that information and problem solving are all related to the cognitive process of an individual (Budak, 2009). According to the behaviouristic approach, cognition comprises of all the intrinsic activities between the stimulant and the behaviour and performs three functions, which are stated as ordering the information and adjustment, identifying and defining the objects, and attributing meaning and value. The first research on metacognitions was conducted by John Flavell, who first introduced the term. Flavell (1979) claimed that the term metacognition is related to an individual's knowledge on cognitive processes. Metacognition can also be explained as thinking about thinking. In other words, metacognition is the individuals' being aware of intellectual processes, observing and Identification how they learn and developing suitable strategies accordingly (Bakircioglu, 2012).

Metacognition enables individuals to acquire, comprehend, keep and recall the knowledge. It increases the effectiveness of learning and effects the critical thinking and problem solving skills, thus enabling individuals to regulate their learning processes by themselves (Hartman, 1998). Briefly, metacognition helps individuals realize 'what they know' and 'what they do not know' (Dirkes, 1985). Flavell (1979) has discussed the metacognitive strategies by which cognitive processes can be controlled and led in three groups and searched for answers to the following questions:

- Planning: "How will I learn?"

- Observation: "How can I correct my deficiencies and mistakes?"

- Evaluation: "How did I learn this subject?"

Flexibility is the ability of individuals to use the acquired knowledge in different conditions. Cognitive flexibility, which is defined as the ability to pass from one thought to another to accommodate oneself to the changing stimulants in the environment (Dennis and Vander, 2010) is the ability to arrange information processing strategies under new and unexpected situations. It enables individuals to use the most effective learning strategies about the subjects they are trying to learn and to determine the stages of solving a problem they have faced with. It is a process including multiple dimensions such as producing and processing multiple thoughts at once, being flexible in adapting to new situations, recognizing alternative ways and choices, being competent, making use of alternatives, changing the objectives in accordance with the situation and adaptation to the environment (Martin and Rubin, 1995; Martin and Anderson, 1998). Cognitive flexibility can be acquired through new experiences. Individuals with cognitive flexibility do not avoid communication abstain from encountering unfamiliar situations. They are able to try new methods, use various information processing strategies together, adapt to new and unexpected environmental changes easily and produce alternative ideas. However, the individuals who lack this skill support dysfunctional thoughts and beliefs and are rigid in their ideas (Martin and Anderson, 1998).

One of the basic objectives of education is to enable students to learn problem solving strategies. At this stage, it is important for teachers to observe their students about where and when to use the most effective strategies to solve the problems and to direct them accordingly (Demirsöz, 2014). Therefore, teachers are supposed to provide their students with cognitive strategies, help them learn how to use those strategies in learning process, guide them and give them feedback on where and when those strategies are useful (Demirsöz, 2014) cited from Santrock (2004)). The role and importance of cognitive flexibility and metacognitive learning strategies in teaching the subjects in Social Studies Coursebook is an incontrovertible fact. Social Studies is a content area instructional program in which basic social sciences attainments are transferred to students considering their ages, physical conditions and states of mind (Yazici, 2006). Current Social Studies Curriculum is designed within seven learning areas and it requires students to use metacognitive skills in learning process effectively (Social Studies Curriculum, 2018). With this study, the researcher aims to investigate the relation between the cognitive flexibility skills and metacognitive learning strategies of social studies teacher candidates in terms of different variables.

\section{Method}

\subsection{The Model of the Research}

Educational researches generally aim to determine the attitudes, beliefs and opinions of a specific group on a specific subject. This research is designed in relational screening model within general survey model. Relational screening models are research models whose purpose is to determine the existence and degree of covariance between two or more variables (Karasar, 2004).

\subsection{Study Group}

The study group of this research consists of 150 social studies teacher candidates (94 females and 56 males) who have contributed to the research on voluntary basis and study in the Department of Social Studies Education at a state university in the Central Anatolia Region. 


\subsection{Data Collection Tools}

The data were collected with a 'Personal Profile Form' prepared by the researcher, 'Cognitive Flexibility Scale' developed by Martin and Rubin (1995) and adapted to Turkish by Celikkaleli (2014), and 'Metacognitive Learning Strategies Identification Scale” developed by Cöğenli and Güven (2014). The internal consistency coefficient of the Cognitive Flexibility Scale was .67 when it included the second item. However, when the second item was excluded from the scale, the internal consistency coefficient was .73. The internal consistency coefficient was calculated as .74 in the study conducted by Celikkaleli (2014). After the Metacognitive Learning Strategies Identification Scale was applied, the Cronbach alpha values were found as; Planning strategies .89, Observing strategies .91, Evaluation strategies .78 and Emotional strategies .83. The reliability coefficient of the planning, observing, evaluation and emotional strategies in the study conducted by Cöğenli and Güven (2014) were found as .76, .68, .58 and .53 respectively. According to these values, both scales were found reliable.

\subsection{Data Analysis}

The arithmetic mean scores of the social studies teacher candidates' replies to the questions in the Cognitive Flexibility were calculated on the basis of the following frequencies: Strongly Disagree $(1.00<\overline{\mathrm{X}} \leq 1.84)$, Disagree $(1.85<\overline{\mathrm{X}} \leq 2.67)$, Partly Disagree $(2.68<\overline{\mathrm{X}} \leq 3.50)$, Partly Agree $(3.51<\overline{\mathrm{X}} \leq 4.33)$, Agree $(4.34<\overline{\mathrm{X}} \leq 5.16)$, Strongly Agree $(5.17<\overline{\mathrm{X}} \leq 6.00)$. The arithmetic mean scores of the social studies teacher candidates' replies to the questions in the metacognitive learning strategies Identification scale were calculated on the basis of the following frequencies: Strongly Disagree $(1.00<\overline{\mathrm{X}} \leq 1.80)$, Disagree $(1.81<\overline{\mathrm{X}} \leq 2.60)$, Undecided $(2.61<\overline{\mathrm{X}} \leq 3.40)$, Agree $(3.41<\overline{\mathrm{X}} \leq 4.20)$ and Strongly Agree $(4.21<\overline{\mathrm{X}} \leq 5.00)$. Whether the scores of the participants they got from the cognitive flexibility and metacognitive learning strategies Identification scale differed significantly in terms of gender and ownership of a PC was analysed through independent samples t-test.

\section{Findings}

\subsection{The Cognitive Flexibility Levels of the Teacher Candidates}

Table-1. The findings as to the question "what are the cognitive flexibility levels of social studies teacher candidates?"

\begin{tabular}{c|l|c|c|c}
\hline $\begin{array}{c}\text { Item } \\
\text { no }\end{array}$ & Item & $\mathbf{n}$ & $\overline{\boldsymbol{x}}$ & Level \\
\hline 1 & I can express an opinion/idea in many ways. & 150 & 4.78 & I Agree \\
\hline 2 & I avoid new and unusual situations. & 150 & 3.49 & Partly Disagree \\
\hline 3 & $\begin{array}{l}\text { I feel as if I will never manage to make a decision on anything (about } \\
\text { future, while shopping, about the opposite sex, etc.) }\end{array}$ & 150 & 3.40 & Partly Disagree \\
\hline 4 & I can behave in accordance with any situation. & 150 & 4.55 & I Agree \\
\hline 5 & I can find practical/useful solutions to seemingly unsovable problems. & 150 & 4.46 & I Agree \\
\hline 6 & I cannot develop different perspectives while I decide how to behave. & 150 & 3.96 & Partly Agree \\
\hline 7 & I would like to find creative solutions to the problems. & 150 & 4.80 & I Agree \\
\hline 8 & My behaviour is the result of my conscious decisions. & 150 & 4.55 & I Agree \\
\hline 9 & I can behave in many ways under any situation. & 150 & 4.33 & Partly Agree \\
\hline 10 & In real life, I have difficulty in using my knowledge on a specific field. & 150 & 3.21 & Partly Disagree \\
\hline 11 & $\begin{array}{l}\text { I'd prefer to listen to and evaluate alternative solutions to overcome a } \\
\text { problem. }\end{array}$ & 150 & 4.82 & I Agree \\
\hline 12 & I have the self-confidence necessary to do a work in various ways. & 150 & 4.58 & I Agree \\
\hline & General average & 150 & 4.25 & Partly Agree \\
\hline
\end{tabular}

The arithmetic mean scores of the social studies teacher candidates' replies to the questions in the cognitive flexibility scale were calculated on the basis of the following frequencies: Strongly Disagree $(1.00<\overline{\mathrm{X}} \leq 1.84)$, Disagree $(1.85<\overline{\mathrm{X}} \leq 2.67)$, Partly Disagree $(2.68<\overline{\mathrm{X}} \leq 3.50)$, Partly Agree $(3.51<\overline{\mathrm{X}} \leq 4.33)$, Agree $(4.34<\overline{\mathrm{X}} \leq 5.16)$, Strongly Agree $(5.17<\overline{\mathrm{X}} \leq 6.00)$. The results of the analysis in Table 1 show that the lowest cognitive flexibility point average $(\overline{\mathrm{X}}=3.21)$ of the teacher candidates are in item 10; "In real life, I have difficulty in using my knowledge on a specific field". However, the item with the highest cognitive flexibility point average $(\overline{\mathrm{X}}=4.82)$ is item 11; "I'd prefer to listen to and evaluate alternative solutions to overcome a problem". It can be seen that the social studies teacher candidates' cognitive flexibility point averages in general are at "Partly Agree” level (3.51< $\overline{\mathrm{X}}$ $\leq 4.33)$.

The arithmetic mean scores of the social studies teacher candidates' replies to the questions in the metacognitive learning strategies Identification scale were calculated on the basis of the following frequencies: Strongly Disagree $(1.00<\overline{\mathrm{X}} \leq 1.80)$, Disagree $(1.81<\overline{\mathrm{X}} \leq 2.60)$, Undecided $(2.61<\overline{\mathrm{X}} \leq 3.40)$, Agree $(3.41<\overline{\mathrm{X}} \leq 4.20)$ and Strongly Agree $(4.21<\overline{\mathrm{X}} \leq 5.00)$. The results of the analysis in Table 2 show that the lowest point average $(\overline{\mathrm{X}}$ $=3.33$ ) of the teacher candidates in the metacognitive learning strategies Identification scale are in item 19; "I can overcome such negative issues as stress, worry and too much anxiety while studying”. However, the item with the highest metacognitive learning strategies Identification point average $(\bar{X}=3.90)$ is item 11 ; "I prefer to study in a silent environment". The metacognitive learning strategies Identification levels of teacher candidates are high (I Agree) $(3.41<\overline{\mathrm{X}} \leq 4.20)$ in 27 items and medium (Undecided) $(2.61<\overline{\mathrm{X}} \leq 3.40)$ in 1 item. It can be inferred from the findings that the metacognitive learning strategies Identification point averages of social studies teacher candidates are high level (I Agree) $(3.41<\bar{X} \leq 4.20)$. Thus, it can be stated that the metacognitive learning strategies Identification levels of social studies teacher candidates are high. 
Table-2. The findings as to the question "what are the metacognitive learning strategies identification levels of social studies teacher

\begin{tabular}{|c|c|c|c|c|}
\hline Item no & Item & $\mathbf{n}$ & $\overline{\boldsymbol{x}}$ & Level \\
\hline 1 & I think over why the subject I will learn is necessary for me. & 150 & 3.69 & I Agree \\
\hline 2 & I determine what strategies to use before I start to study. & 150 & 3.55 & I Agree \\
\hline 3 & $\begin{array}{l}\text { I think over how the methods and approaches that help me reach my goals will } \\
\text { serve me in my next study. }\end{array}$ & 150 & 3.68 & I Agree \\
\hline 4 & I place more emphasis on the points that take my attention while studying. & 150 & 3.81 & I Agree \\
\hline 5 & I try to develop a positive attitude to the subject on which I study. & 150 & 3.73 & I Agree \\
\hline 6 & I determine my objective as to the subject I will learn. & 150 & 3.61 & I Agree \\
\hline 7 & I notice my faults and correct them. & 150 & 3.66 & I Agree \\
\hline 8 & I make use of resources for the points I feel incompetent. & 150 & 3.75 & I Agree \\
\hline 9 & Before I start to study, I think over what I need as to the subject I will learn. & 150 & 3.79 & I Agree \\
\hline 10 & $\begin{array}{l}\text { If I'm not efficient while studying, I think over what kinds of changes I must } \\
\text { make. }\end{array}$ & 150 & 3.69 & I Agree \\
\hline 11 & I prefer to study in a silent environment. & 150 & 3.90 & I Agree \\
\hline 12 & While I learn something new, I think over how I can learn better. & 150 & 3.89 & I Agree \\
\hline 13 & I organize the published resources I need during learning process. & 150 & 3.67 & I Agree \\
\hline 14 & $\begin{array}{l}\text { I think over how I can make use of the newly acquired knowledge in other } \\
\text { learning conditions. }\end{array}$ & 150 & 3.65 & I Agree \\
\hline 15 & I think that motivation is important in my studying efficiently. & 150 & 3.72 & I Agree \\
\hline 16 & I replace the learning strategies that do not serve my learning. & 150 & 3.77 & I Agree \\
\hline 17 & $\begin{array}{l}\text { I think over whether there are other methods with which I can understand the } \\
\text { subject better. }\end{array}$ & 150 & 3.63 & I Agree \\
\hline 18 & I choose the materials I need for the subject I will learn. & 150 & 3.70 & I Agree \\
\hline 19 & $\begin{array}{l}\text { I can overcome such negative issues as stress, worry and too much anxiety while } \\
\text { studying. }\end{array}$ & 150 & 3.33 & Undecided \\
\hline 20 & I ask myself questions about the subject I study on. & 150 & 3.71 & I Agree \\
\hline 21 & I take a break when I'm distracted while studying. & 150 & 3.88 & I Agree \\
\hline 22 & I make plans in accordance with my learning objectives. & 150 & 3.71 & I Agree \\
\hline 23 & I check whether I have achieved my objective. & 150 & 3.73 & I Agree \\
\hline 24 & $\begin{array}{l}\text { I make positive self-talks such as "I can understand the text if I read it once } \\
\text { more." or I can manage this project." In order to minimize my anxiety. }\end{array}$ & 150 & 3.71 & I Agree \\
\hline 25 & I observe my comprehension level according to my study plan. & 150 & 3.69 & I Agree \\
\hline 26 & Before I start to study, I determine what kind of information I need. & 150 & 3.75 & I Agree \\
\hline 27 & $\begin{array}{l}\text { In order to keep my motivation, I think that I will be successful in the subject I } \\
\text { study on. }\end{array}$ & 150 & 3.71 & I Agree \\
\hline \multirow[t]{2}{*}{28} & I plan the time I will allocate for studying. & 150 & 3.67 & I Agree \\
\hline & General average & 150 & 3.71 & I Agree \\
\hline
\end{tabular}

\subsection{The Findings as to the $1^{\text {st }}$ Sub-Problem}

Table-3. The independent t-test results of the scale averages on social studies teacher candidates' cognitive flexibility levels in terms of gender

\begin{tabular}{cc|c|c|c|c|c|c}
\hline Gender & $\mathbf{n}$ & $\overline{\boldsymbol{x}}$ & $\mathbf{S s}$ & $\mathbf{s d}$ & $\mathbf{t}$ & $\mathbf{p}$ \\
\hline Female & 94 & 50.37 & 6.10 & \multirow{2}{*}{148} & \multirow{2}{*}{1.22} & \multirow{2}{*}{$.224^{*}$} \\
\hline Male & 56 & 51.89 & 9.13 & \\
\hline Note ${ }^{*} \mathrm{p}>.05$.
\end{tabular}

Table 3 indicates that there is no significant difference between the cognitive flexibility levels and genders of the social studies teacher candidates $\left[\mathrm{t}_{(148)}=1.22 ; \mathrm{p}>\right.$.05]. It can be concluded from this finding that there exists no relation between the cognitive flexibility levels and genders of the social studies teacher candidates.

Table-4. The Independent t-Test results of the scale averages on social studies teacher candidates' metacognitive learning strategies identification levels in terms of gender.

\begin{tabular}{|c|c|c|c|c|c|c|c|}
\hline Factors & Gender & $\mathbf{n}$ & $\bar{X}$ & Ss & sd & $\mathbf{t}$ & $\mathbf{p}$ \\
\hline \multirow[t]{2}{*}{ Planning strategies } & Female & 94 & 34.13 & 6.05 & \multirow{2}{*}{148} & \multirow{2}{*}{2.308} & \multirow{2}{*}{$.022^{*}$} \\
\hline & Male & 56 & 31.50 & 7.78 & & & \\
\hline \multirow[t]{2}{*}{ Observing strategies } & Female & 94 & 31.00 & 5.61 & \multirow[t]{2}{*}{148} & \multirow{2}{*}{2.593} & \multirow{2}{*}{$.010^{*}$} \\
\hline & Male & 56 & 28.29 & 7.08 & & & \\
\hline \multirow{2}{*}{ Evaluation strategies } & Female & 94 & 15.05 & 2.78 & \multirow[t]{2}{*}{148} & \multirow{2}{*}{1.498} & \multirow{2}{*}{.136} \\
\hline & Male & 56 & 14.27 & 3.60 & & & \\
\hline \multirow[t]{2}{*}{ Emotional strategies } & Female & 94 & 26.41 & 4.89 & \multirow[t]{2}{*}{148} & \multirow[t]{2}{*}{1.523} & \multirow[t]{2}{*}{.130} \\
\hline & Male & 56 & 25.05 & 5.91 & & & \\
\hline \multirow[t]{2}{*}{ Total } & Female & 94 & 106.60 & 18.30 & \multirow[t]{2}{*}{148} & \multirow[t]{2}{*}{2.183} & \multirow[t]{2}{*}{$.031 *$} \\
\hline & Male & 56 & 99.11 & 23.35 & & & \\
\hline
\end{tabular}

Table 4 shows that there is a significant difference between the metacognitive learning strategies levels of social studies teacher candidates in planning strategies $\left(\mathrm{t}_{(148)}=2.308 ; \mathrm{p}<.05\right)$, Observing Strategies $\left(\mathrm{t}_{(148)}=2.593\right.$; $\mathrm{p}<.05)$ sub-factors and the total scale point $\left(\mathrm{t}_{(148)}=2.183 ; \mathrm{p}<.05\right)$ in terms of gender. However, no such significant difference is found in Evaluation Strategies $\left(\mathrm{t}_{(148)}=1.498 ; \mathrm{p}>.05\right)$ and Emotional Strategies $\left(\mathrm{t}_{(148)}=1.523 ; \mathrm{p}>.05\right)$ sub- 
factors. According to the findings, it is concluded that the metacognitive learning strategies Identification levels of female social studies teacher candidates are higher than those of male teacher candidates in Planning Strategies and Observing Strategies sub-factors and the scale as a whole.

\subsection{The Findings as to the $2^{\text {nd }}$ Sub-Problem}

Table-5. One-way ANOVA results as to social studies teacher candidates' cognitive flexibility levels in terms of grade variable.

\begin{tabular}{|c|c|c|c|c|c|c|c|c|c|c|}
\hline Grade & $\mathbf{n}$ & $\overline{\mathrm{X}}$ & Ss & VK & KT & sd & КO & $\mathbf{F}$ & $\mathbf{p}$ & $\begin{array}{c}\text { Source of difference } \\
\text { (Scheffe) }\end{array}$ \\
\hline 1st Grade & 49 & 51.39 & 7.47 & $\begin{array}{l}\text { Between } \\
\text { Groups }\end{array}$ & 484.389 & 3 & 161.463 & \multirow{5}{*}{3.081} & \multirow{5}{*}{$.029 *$} & \multirow{5}{*}{$3-4$} \\
\hline 2nd Grade & 50 & 50.10 & 7.02 & $\begin{array}{l}\text { Within } \\
\text { Groups }\end{array}$ & 7650.071 & 146 & 52.398 & & & \\
\hline 3rd Grade & 30 & 53.77 & 5.82 & Total & 8134.460 & 149 & & & & \\
\hline 4th Grade & 21 & 47.86 & 8.87 & & & & & & & \\
\hline Total & 150 & 50.94 & 7.39 & & & & & & & \\
\hline
\end{tabular}

Table 5 indicates that there is a significant difference between the social studies teacher candidates' cognitive flexibility levels in terms of grade variable $\left[\mathrm{F}_{(3-146)}=3.081, \mathrm{p}<.05\right]$. It is concluded from the findings that the cognitive flexibility levels of social studies teacher candidates studying at the 3rd grade are higher than those of the teacher candidates studying at the 4th grade.

Table-6. One-Way ANOVA results as to social studies teacher candidates' metacognitive learning strategies identification levels in terms of grade variable.

\begin{tabular}{|c|c|c|c|c|c|c|c|c|c|c|c|}
\hline 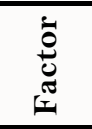 & Grade & $\mathbf{n}$ & $\overline{\mathrm{X}}$ & Ss & VK & KT & sd & KO & $\mathbf{F}$ & $\mathbf{p}$ & $\begin{array}{c}\text { Source of } \\
\text { Difference } \\
\text { (Scheffe) }\end{array}$ \\
\hline \multirow{5}{*}{ 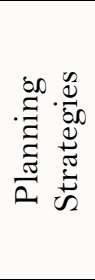 } & 1st Grade & 49 & 33.10 & 6.67 & $\begin{array}{c}\text { Between } \\
\text { Groups }\end{array}$ & 355.274 & 3 & 118.425 & \multirow{5}{*}{2.611} & \multirow{5}{*}{.054} & \\
\hline & 2nd Grade & 50 & 32.70 & 7.54 & $\begin{array}{l}\text { Within } \\
\text { Groups }\end{array}$ & 6621.499 & 146 & 45.353 & & & \\
\hline & 3rd Grade & 30 & 35.77 & 5.46 & Total & 6976.773 & 149 & & & & \\
\hline & 4th Grade & 21 & 30.57 & 6.46 & & & & & & & \\
\hline & Total & 150 & 33.15 & 6.84 & & & & & & & \\
\hline \multirow{5}{*}{ 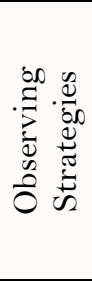 } & 1st Grade & 49 & 29.80 & 6.24 & $\begin{array}{c}\text { Between } \\
\text { Groups }\end{array}$ & 294.729 & 3 & 98.243 & \multirow{5}{*}{2.536} & \multirow{5}{*}{.059} & \\
\hline & 2nd Grade & 50 & 29.18 & 6.92 & $\begin{array}{l}\text { Within } \\
\text { Groups }\end{array}$ & 5655.244 & 146 & 38.735 & & & \\
\hline & 3rd Grade & 30 & 32.67 & 4.66 & Total & 5949.973 & 149 & & & & \\
\hline & 4th Grade & 21 & 28.52 & 6.38 & & & & & & & \\
\hline & Total & 150 & 29.99 & 6.32 & & & & & & & \\
\hline \multirow{5}{*}{ 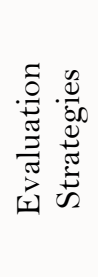 } & 1st Grade & 49 & 14.82 & 3.00 & $\begin{array}{c}\text { Between } \\
\text { Groups }\end{array}$ & 90.488 & 3 & 30.163 & \multirow{5}{*}{3.241} & \multirow{5}{*}{$.024^{*}$} & \multirow{5}{*}{$3-4$} \\
\hline & 2nd Grade & 50 & 14.46 & 3.36 & $\begin{array}{l}\text { Within } \\
\text { Groups }\end{array}$ & 1358.872 & 146 & 9.307 & & & \\
\hline & 3rd Grade & 30 & 16.07 & 2.83 & Total & 1449.36 & 149 & & & & \\
\hline & 4th Grade & 21 & 13.48 & 2.66 & & & & & & & \\
\hline & Total & 150 & 14.76 & 3.12 & & & & & & & \\
\hline \multirow{5}{*}{ 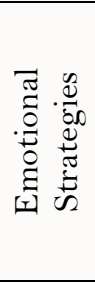 } & 1st Grade & 49 & 25.82 & 4.88 & $\begin{array}{c}\text { Between } \\
\text { Groups }\end{array}$ & 355.393 & 3 & 118.464 & \multirow{5}{*}{4.484} & \multirow{5}{*}{$.005^{*}$} & \multirow{5}{*}{$\begin{array}{l}3-2 \\
3-4\end{array}$} \\
\hline & 2nd Grade & 50 & 24.76 & 5.92 & $\begin{array}{l}\text { Within } \\
\text { Groups }\end{array}$ & 3857.300 & 146 & 26.420 & & & \\
\hline & 3rd Grade & 30 & 28.83 & 3.90 & Total & 4212.693 & 149 & & & & \\
\hline & 4th Grade & 21 & 24.67 & 5.29 & & & & & & & \\
\hline & Total & 150 & 25.91 & 5.32 & & & & & & & \\
\hline \multirow{5}{*}{ ت્ّ } & 1st Grade & 49 & 103.53 & 19.70 & $\begin{array}{c}\text { Between } \\
\text { Groups }\end{array}$ & 3 & 3 & $\begin{array}{c}1332.94 \\
0\end{array}$ & \multirow{5}{*}{3.293} & \multirow{5}{*}{$.022^{*}$} & \multirow{5}{*}{$\begin{array}{l}3-1 \\
3-2 \\
3-4\end{array}$} \\
\hline & 2nd Grade & 50 & 101.10 & 22.92 & $\begin{array}{l}\text { Within } \\
\text { Groups }\end{array}$ & 146 & 146 & 404.816 & & & \\
\hline & 3rd Grade & 30 & 113.33 & 15.34 & Total & 149 & 149 & & & & \\
\hline & 4th Grade & 21 & 97.24 & 19.88 & & & & & & & \\
\hline & Total & 150 & 103.80 & 12.54 & & & & & & & \\
\hline
\end{tabular}

Table 6 shows that there exists no significant difference between the social studies teacher candidates' grades and metacognitive learning strategies in terms of Planning Strategies $\left(\mathrm{F}_{(3-146)}=2.611, \mathrm{p}>\right.$.05) and Observing Strategies $\left(\mathrm{F}_{(3-146)}=2.536, \mathrm{p}>\right.$.05) factors. However, a significant difference has been found in Evaluation Strategies $\left(\mathrm{F}_{(3-146)}=3.241, \mathrm{p}<.05\right)$, Emotional Strategies $\left(\mathrm{F}_{(3-146)}=4.484, \mathrm{p}<.05\right)$ and the whole scale in terms of grade variable. The findings reveal that social studies teacher candidates studying at $3^{\text {rd }}$ grade have higher scores in Evaluation Strategies factor than do those studying at the $4^{\text {th }}$ grade. Those who study at the $3^{\text {rd }}$ grade also have higher scores than the ones who study at the $2^{\text {nd }}$ and $4^{\text {th }}$ grades in terms of Emotional Strategies factor. As to the whole scale, it can be stated that the metacognitive learning strategies levels of the social studies teacher candidates studying at the $3^{\text {rd }}$ grade are higher than those of the ones at the $1^{\text {st }}, 2^{\text {nd }}$ and $4^{\text {th }}$ grade students. 


\subsection{The Findings as to the $3^{\text {rd }}$ Sub-Problem}

Table-7. One-Way ANOVA results of the scale averages of social studies teacher candidates' cognitive flexibility levels in terms of general academic achievement.

\begin{tabular}{c|c|c|c|c|c|c|c|c|c|c}
\hline Academic standing & $\mathbf{n}$ & $\overline{\mathrm{X}}$ & $\mathbf{S s}$ & $\mathbf{V K}$ & $\mathbf{K T}$ & $\mathbf{s d}$ & $\mathbf{K O}$ & $\mathbf{F}$ & $\mathbf{p}$ \\
\hline Failed & 8 & 50.00 & 8.60 & $\begin{array}{c}\text { Between } \\
\text { Groups }\end{array}$ & 297.534 & 3 & 99.178 & \\
\hline Average & 86 & 50.13 & 7.32 & $\begin{array}{c}\text { Within } \\
\text { Groups }\end{array}$ & 7836.926 & 146 & 53.678 \\
\hline Successful & 54 & 52.61 & 6.36 & Total & 8134.460 & 149 & \\
\hline Very successful & 2 & 44.50 & 24.75 & & & \\
\hline Total & 150 & 50.94 & 7.39 & & & \\
\hline
\end{tabular}

Note: * $\mathrm{p}>.05$.

Table 7 shows that there is no significant difference between the grades and cognitive flexibility levels of social studies teacher candidates $\left[\mathrm{F}_{(3-146)}=1.848, \mathrm{p}>.05\right]$. The findings reveal that there is no correlation between the cognitive flexibility levels and general academic achievements of social studies teacher candidates.

Table-8. One-Way ANOVA results of the scale averages as to the social studies teacher candidates' levels of metacognitive learning strategies in terms of general academic achievement.

\begin{tabular}{|c|c|c|c|c|c|c|c|c|c|c|c|}
\hline 苞 & $\begin{array}{l}\text { Academic } \\
\text { standing }\end{array}$ & $\mathbf{n}$ & $\bar{X}$ & Ss & VK & KT & sd & KO & $\mathbf{F}$ & p & $\begin{array}{c}\text { Source of } \\
\text { difference } \\
\text { (Scheffe) }\end{array}$ \\
\hline \multirow{5}{*}{ 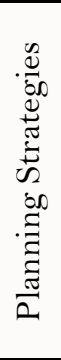 } & 1-Failed & 8 & 29.50 & 8.07 & $\begin{array}{c}\text { Between } \\
\text { Groups }\end{array}$ & 301.894 & 3 & 100.631 & \multirow{5}{*}{2.201} & \multirow{5}{*}{.090} & \\
\hline & 2-Average & 86 & 32.52 & 6.65 & $\begin{array}{l}\text { Within } \\
\text { Groups }\end{array}$ & 6674.879 & 146 & 45.718 & & & \\
\hline & $\begin{array}{c}3- \\
\text { Successful }\end{array}$ & 54 & 34.46 & 6.80 & Total & 6976.773 & 149 & & & & \\
\hline & $\begin{array}{c}\text { 4-Very } \\
\text { successful }\end{array}$ & 2 & 39.00 & 2.83 & & & & & & & \\
\hline & Total & 150 & 33.15 & 6.84 & & & & & & & \\
\hline \multirow{5}{*}{ 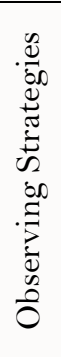 } & 1-Failed & 8 & 24.75 & 8.24 & $\begin{array}{c}\text { Between } \\
\text { Groups }\end{array}$ & 479.814 & 3 & 159.938 & \multirow{5}{*}{4.269} & \multirow{5}{*}{$.006^{*}$} & \multirow{5}{*}{$4-1$} \\
\hline & 2-Average & 86 & 29.64 & 5.82 & $\begin{array}{l}\text { Within } \\
\text { Groups }\end{array}$ & 5470.159 & 146 & 37.467 & & & \\
\hline & $\begin{array}{c}3- \\
\text { Successful } \\
\end{array}$ & 54 & 30.94 & 6.31 & Total & 5949.973 & 149 & & & & \\
\hline & $\begin{array}{c}4-\text { Very } \\
\text { successful }\end{array}$ & 2 & 40.00 & 0.00 & & & & & & & \\
\hline & Total & 150 & 29.99 & 6.32 & & & & & & & \\
\hline \multirow{5}{*}{ 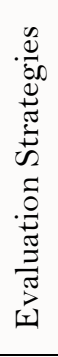 } & 1-Failed & 8 & 12.75 & 3.77 & $\begin{array}{c}\text { Between } \\
\text { Groups }\end{array}$ & 56.720 & 3 & 18.907 & \multirow{5}{*}{1.982} & \multirow{5}{*}{.119} & \\
\hline & 2-Average & 86 & 14.64 & 3.00 & $\begin{array}{l}\text { Within } \\
\text { Groups }\end{array}$ & 1392.640 & 146 & 9.539 & & & \\
\hline & $\begin{array}{c}3- \\
\text { Successful }\end{array}$ & 54 & 15.15 & 3.14 & Total & 1449.360 & 149 & & & & \\
\hline & $\begin{array}{c}4-\text { Very } \\
\text { successful }\end{array}$ & 2 & 17.50 & 2.12 & & & & & & & \\
\hline & Total & 150 & 14.76 & 3.12 & & & & & & & \\
\hline \multirow{5}{*}{ 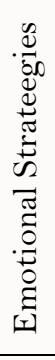 } & 1-Failed & 8 & 22.38 & 6.82 & $\begin{array}{c}\text { Between } \\
\text { Groups }\end{array}$ & 229.225 & 3 & 76.408 & \multirow{5}{*}{2.800} & \multirow{5}{*}{$.042 *$} & \multirow{5}{*}{$\begin{array}{l}3-1 \\
3-2\end{array}$} \\
\hline & 2-Average & 86 & 25.37 & 5.14 & $\begin{array}{l}\text { Within } \\
\text { Groups }\end{array}$ & 3983.468 & 146 & 27.284 & & & \\
\hline & $\begin{array}{c}3- \\
\text { Successful } \\
\end{array}$ & 54 & 27.17 & 5.16 & Total & 4212.693 & 149 & & & & \\
\hline & $\begin{array}{c}\text { 4-Very } \\
\text { successful }\end{array}$ & 2 & 29.00 & 0.00 & & & & & & & \\
\hline & Total & 150 & 25.91 & 5.32 & & & & & & & \\
\hline \multirow{5}{*}{$\stackrel{\pi}{\stackrel{\pi}{0}}$} & 1-Failed & 8 & 89.38 & 25.50 & $\begin{array}{c}\text { Between } \\
\text { Groups }\end{array}$ & 3664.408 & 3 & 1221.469 & \multirow{5}{*}{3.000} & \multirow{5}{*}{$.033 *$} & \multirow{5}{*}{$\begin{array}{l}3-1 \\
4-1\end{array}$} \\
\hline & 2-Average & 86 & 102.17 & 19.64 & $\begin{array}{l}\text { Within } \\
\text { Groups }\end{array}$ & $\begin{array}{c}59437.59 \\
2 \\
\end{array}$ & 146 & 407.107 & & & \\
\hline & $\begin{array}{c}3- \\
\text { Successful } \\
\end{array}$ & 54 & 107.72 & 20.40 & Total & $\begin{array}{c}63102.00 \\
0 \\
\end{array}$ & 149 & & & & \\
\hline & $\begin{array}{c}\text { 4-Very } \\
\text { successful }\end{array}$ & 2 & 125.50 & 4.95 & & & & & & & \\
\hline & Total & 150 & 103.80 & 20.58 & & & & & & & \\
\hline
\end{tabular}

According to Table 8 there is no significant difference between the general academic achievements and metacognitive learning strategies Identification levels of social studies teacher candidates in Planning Strategies $\left(\mathrm{F}_{(3-146)}=2.201, \mathrm{p}>.05\right)$ and Evaluation Strategies $\left(\mathrm{F}_{(3-146)}=1.982, \mathrm{p}>.05\right)$. However, it is seen that there is a significant difference between the metacognitive learning strategies Identification levels and general academic achievement levels in terms of Observing Strategies $\left(\mathrm{F}_{(3-146)}=4.269, \mathrm{p}<.05\right)$, Emotional Strategies $\left(\mathrm{F}_{(3-146)}=2.800\right.$, $\mathrm{p}<.05)$, and the whole scale $\left(\mathrm{F}_{(3-146)}=3.000, \mathrm{p}<.05\right)$. The findings reveal that very successful teacher candidates have 
higher observing strategies Identification levels than do the unsuccessful ones. Similarly, the scores of successful teachers in emotional strategies sub-dimension are higher than those of unsuccessful and average teacher candidates. When it comes to the whole scale, it can be stated that the metacognitive learning strategies Identification levels of successful and very successful teacher candidates are higher than those of the unsuccessful ones.

\subsection{The Findings as to the $4^{\text {th }}$ Sub-Problem}

Table-9. One-Way ANOVA results of the scale averages as to the social studies teacher candidates' levels of cognitive flexibility levels in terms of father's educational attainment variable.

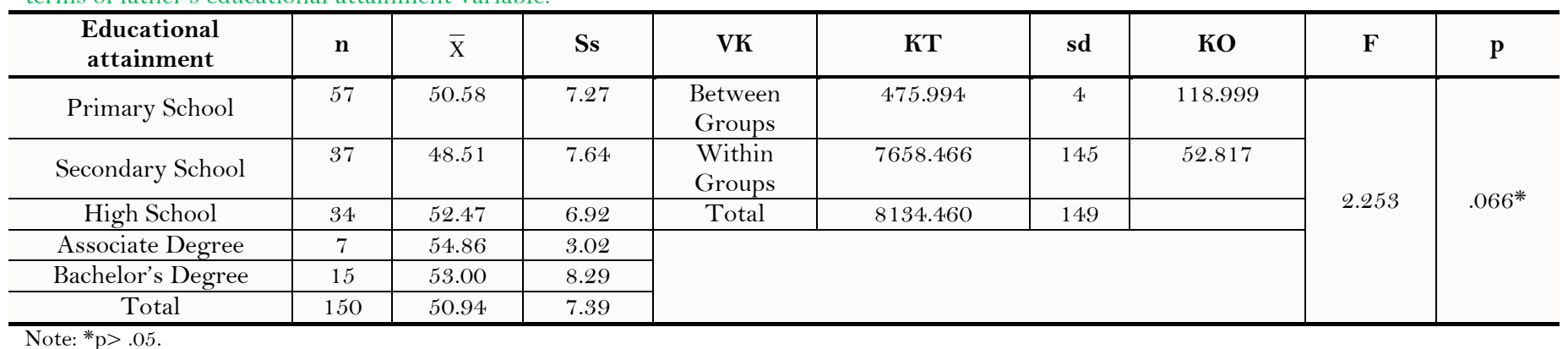

Table 9 shows that there is no significant difference between the father's educational attainment variable and cognitive flexibility levels of social studies teacher candidates $\left[\mathrm{F}_{(4-145)}=2.253, \mathrm{p}>.05\right]$, which is thought to imply that there is no relation between the father's educational attainment and cognitive flexibility levels of social studies teacher candidates.

Table-10. One-Way anova results of the scale averages as to the social studies teacher candidates' levels of metacognitive learning strategies identification levels in terms of father's educational attainment variable.

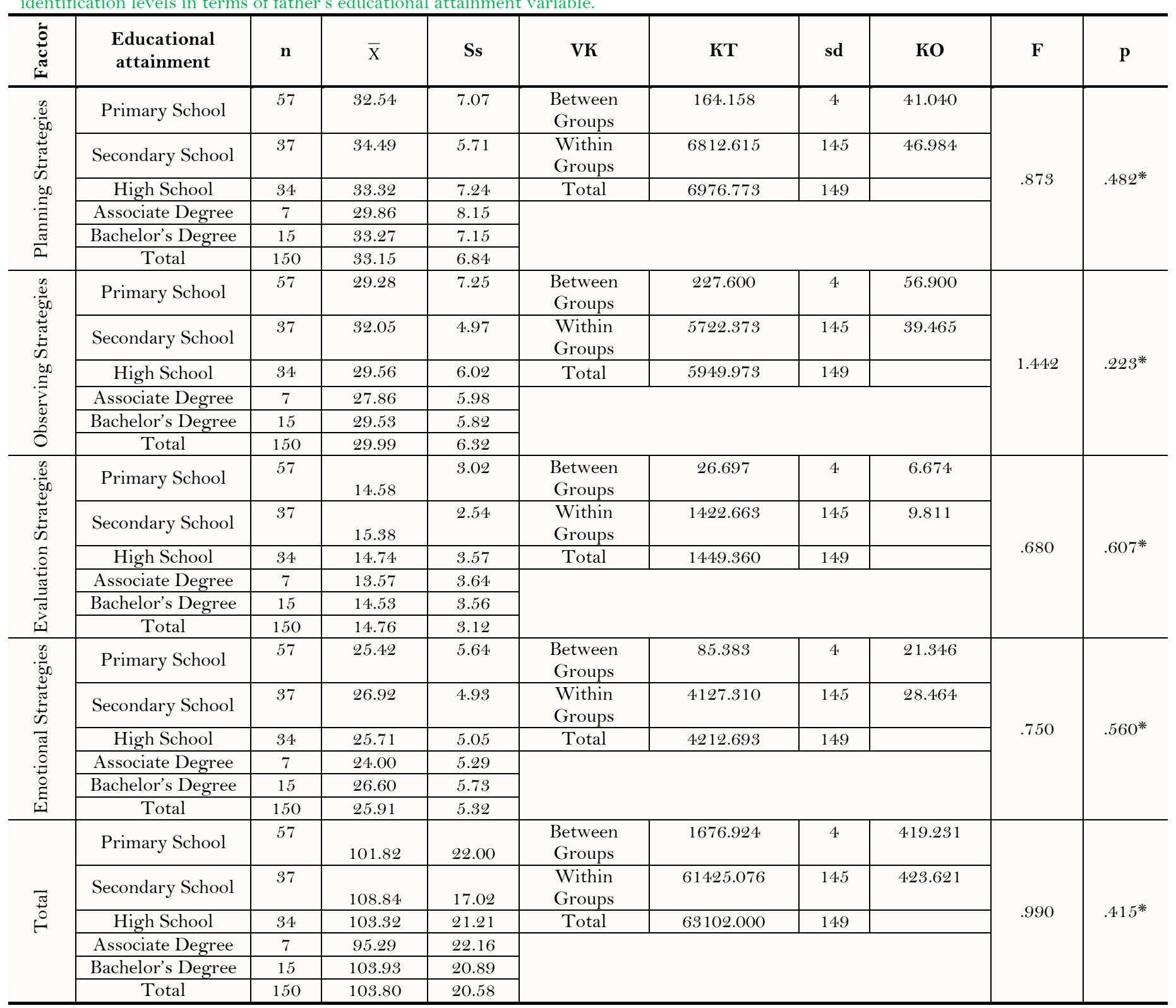

According to Table 10, there are not any significant differences between the social studies teacher candidates' fathers' educational attainment levels in terms of Planning Strategies $\left(\mathrm{F}_{(4-145)}=.873, \mathrm{p}>.05\right)$, Observing Strategies $\left(\mathrm{F}_{(4-145)}=1.442, \mathrm{p}>.05\right)$, Evaluation Strategies $\left(\mathrm{F}_{(4-145)}=.680, \mathrm{p}>.05\right)$, Emotional Strategies $\left(\mathrm{F}_{(4-145)}=.750, \mathrm{p}>.05\right)$ and the whole scale $\left(\mathrm{F}_{(4-145)}=.990, \mathrm{p}>.05\right)$. 


\subsection{The Findings as to the 5th Sub-Problem}

Table-11. One-Way ANOVA results of the scale averages as to the social studies teacher candidates' levels of cognitive flexibility levels in terms of mother's educational attainment variable.

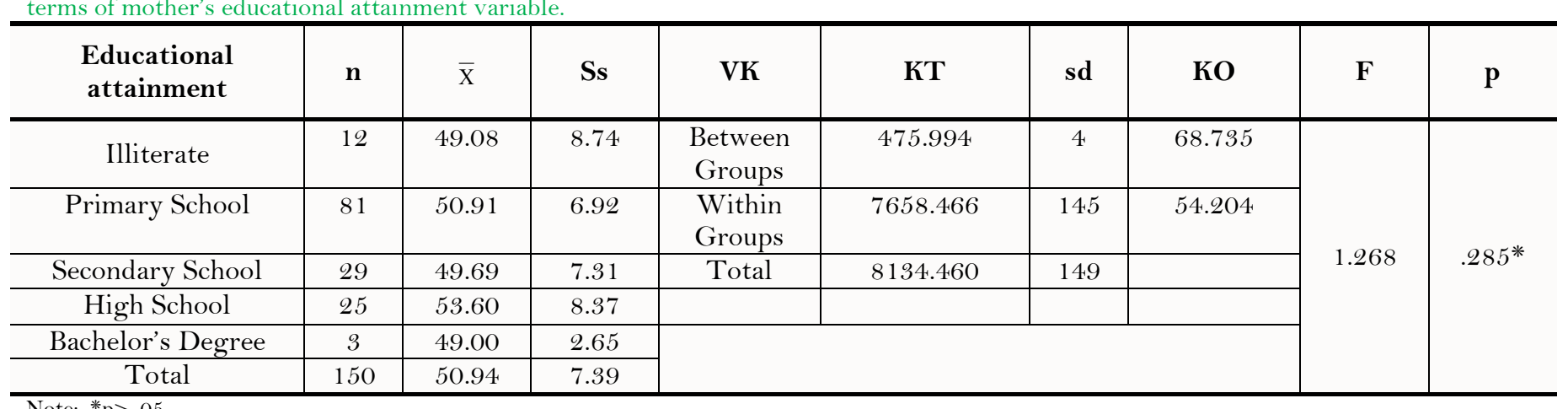

Note: ${ }^{*} \mathrm{p}>.05$

Table 11 shows that there is no significant difference between mother educational attainment levels and cognitive flexibility levels of social studies teacher candidates $\left[\mathrm{F}_{(4-145)}=1.268, \mathrm{p}>.05\right]$, which indicates that there is not a relation between the cognitive flexibility levels and mother's educational attainment.

Table-12. One-Way ANOVA results of the scale averages as to the social studies teacher candidates' levels of metacognitive learning strategies identification levels in terms of mother's educational attainment variable.

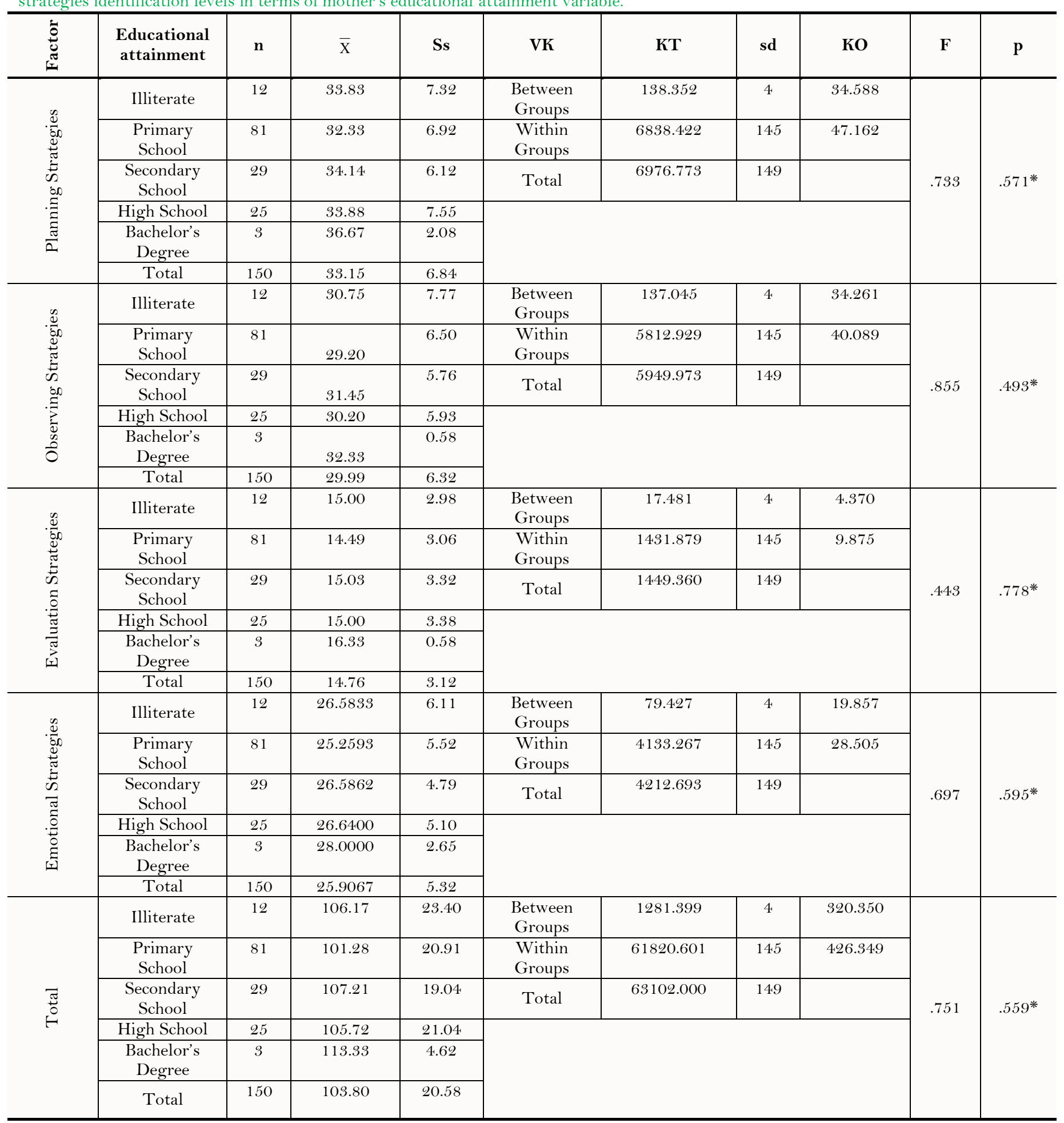

Note: ${ }^{*} \mathrm{p}>.05$

It can be understood from the data in Table 12 that there is no significant difference between social studies teacher candidates' mother educational attainment levels and Planning Strategies $\left(\mathrm{F}_{(4-145)}=.733\right.$, $\left.\mathrm{p}>.05\right)$, Observing 
Strategies $\left(\mathrm{F}_{(4-145)}=.855, \mathrm{p}>.05\right)$, Evaluation Strategies $\left(\mathrm{F}_{(4-145)}=.443\right.$, $\left.\mathrm{p}>.05\right)$, Emotional Strategies $\left(\mathrm{F}_{(4-145)}=.697\right.$, $\mathrm{p}>.05)$ and the whole scale $\left(\mathrm{F}_{(4-145)}=.751, \mathrm{p}>.05\right)$.

\subsection{The Findings as to the $6^{\text {th }}$ Sub-Problem}

Table-13. One-Way ANOVA results of the scale averages as to the social studies teacher candidates' levels of cognitive flexibility levels in terms of the longest resided settlement variable.

\begin{tabular}{c|c|c|c|c|c|c|c|c|c|c|}
\hline Settlement & $\mathbf{n}$ & $\overline{\mathrm{X}}$ & $\mathbf{S s}$ & $\mathbf{V K}$ & $\mathbf{K T}$ & $\mathbf{s d}$ & $\mathbf{K O}$ & $\mathbf{F}$ & $\mathbf{p}$ \\
\hline City & 76 & 50.99 & 8.07 & Between Groups & 65.719 & 2 & 32.859 & \\
\hline Town & 42 & 50.07 & 7.43 & Within Groups & 8068.741 & 147 & 54.889 \\
\hline Village & 32 & 51.97 & 5.46 & Total & 8134.460 & 149 & \\
\hline Total & 150 & 50.94 & 7.39 & & & \\
\hline Note: ${ }^{*}$ p $>.05$.
\end{tabular}

It is seen in Table 13 that there is no significant difference between social studies teacher candidates' longest resided settlements and cognitive flexibility levels $\left[\mathrm{F}_{(2-147)}=.599, \mathrm{p}>.05\right]$. As a result, it can be claimed that there is not a relation between the longest resided settlement variable and cognitive flexibility level.

Table-14. One-Way ANOVA Results of the Scale Averages as to the Social Studies Teacher Candidates' Levels of Metacognitive Learning Strategies Identification Levels in terms of the Longest Resided Settlement Variable.

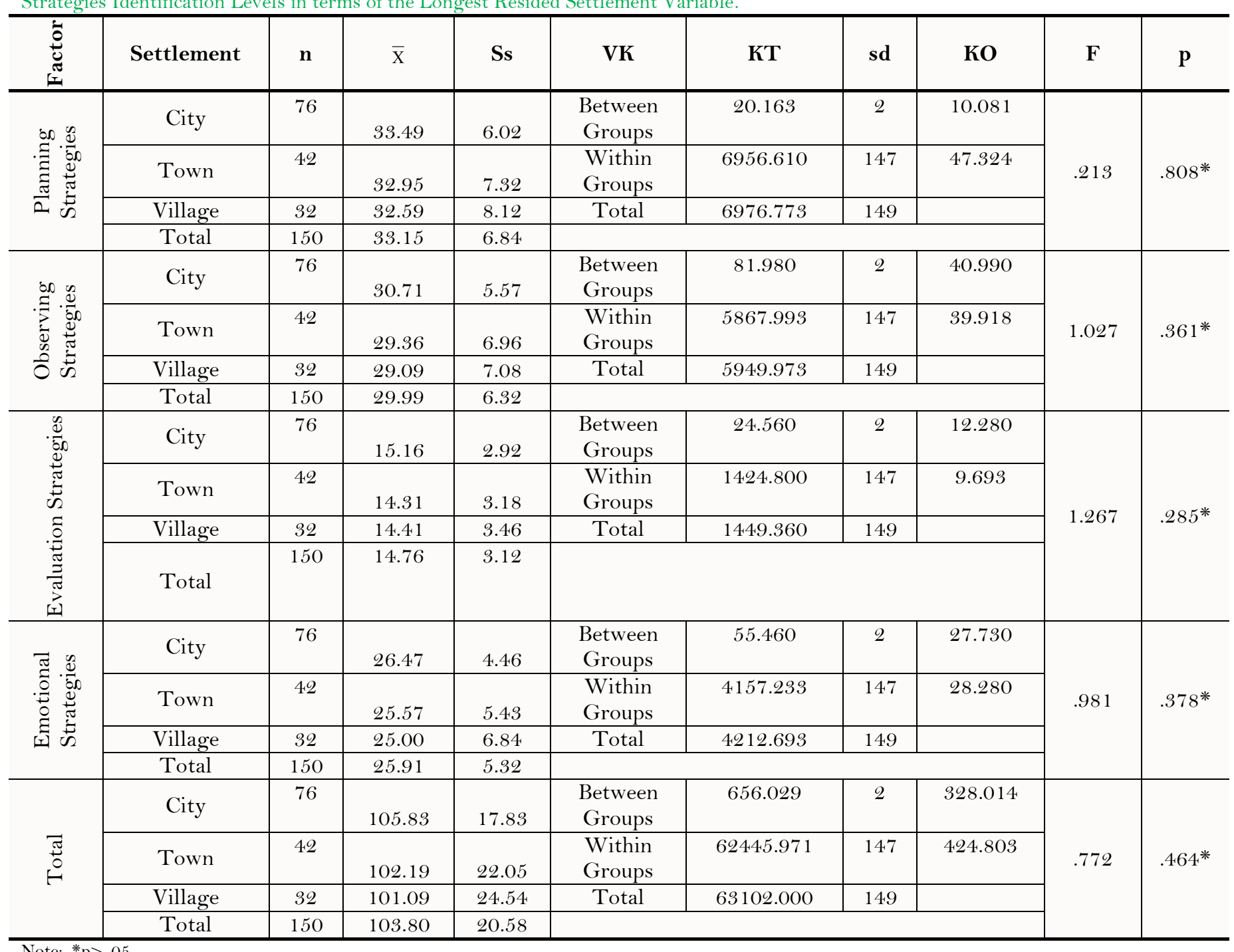

According to Table 14 there is not a significant difference between social studies teachers candidates' longest resided settlement levels and Planning Strategies $\left(\mathrm{F}_{(2-147)}=.213, \mathrm{p}>.05\right)$, Observing Strategies $\left(\mathrm{F}_{(2-147)}=1.027\right.$, $\mathrm{p}>.05)$, Evaluation Strategies $\left(\mathrm{F}_{(2-147)}=1.267, \mathrm{p}>.05\right)$, Emotional Strategies $\left(\mathrm{F}_{(2-147)}=.981, \mathrm{p}>.05\right)$ factors and the whole scale $\left(\mathrm{F}_{(2-147)}=.772, \mathrm{p}>.05\right)$.

Table 15 shows that there is a negative, low and insignificant relation between social studies teacher candidates' cognitive flexibility levels and metacognitive learning strategies Identification levels [ $\mathrm{r}=.898 ; \mathrm{p}>0.01]$.

Table-15. Pearson Product-Moment Correlation Coefficient results for the relation between the cognitive flexibility and metacognitive learning strategies Identification levels of social studies teacher candidates.

\begin{tabular}{c|c|c}
\hline & Cognitive flexibility & $\begin{array}{c}\text { Metacognitive learning strategies } \\
\text { identification }\end{array}$ \\
\hline Cognitive flexibility & 1 & $-.011^{* * *}$ \\
\hline Metacognitive learning strategies identification & $-.011^{* *}$ & 1 \\
\hline Note: ${ }^{* *} \mathrm{p}>.01$. &
\end{tabular}

\section{Conclusion}

In this study, the relation between the cognitive flexibility levels and metacognitive learning strategies Identification levels of social studies teacher candidates is investigated. The study also tries to find out whether 
these variables differ significantly in terms of gender, age, grade, parents' educational attainment and the mostly resided settlement. The findings indicate that the cognitive flexibility levels of social studies teacher candidates are at medium (partly agree) level. Cognitive awareness is at the centre of recognizing the learning to learn skills (Duman, 2011). Teaching profession is directly related to human. Teachers meet many individuals with different personality, mood and behaviours during their careers. A good education requires teaching students how to learn, remember, motivate, and control and direct their own learning (Weinstein and Mayer, 1986). Teacher candidates are supposed to have high cognitive flexibility for an effective teaching, which makes it necessary to investigate the factors that affect the cognitive flexibility levels of teacher candidates. Activities to improve cognitive flexibility skills of students should be increased as it is essential for teachers to adapt themselves to unexpected situations.

No significant was found between social studies teacher candidates' cognitive flexibility levels and gender variable, which corresponds to the findings of the studies by Diril (2011) and Celikkaleli (2014). However, Altunkol (2011) and Sapmaz and Doğan (2013) found that the cognitive flexibility scores of the male are higher than those of the female. Getting different findings from the same variable is in the nature of social sciences. Cognitive flexibility is one's belief that the results of their behaviours will be positive and successful (Martin and Anderson, 1998). The findings of the study show that the social, academic and cultural cognitive lives of teacher candidates are similar. It is concluded that neither cognitive flexibility levels nor metacognitive learning strategies Identification levels of social studies teacher candidates differ significantly in terms of father's and mother's educational attainment level and mostly resided settlement variables. However, Bilgin (2009) found that cognitive flexibility is related with father and mother's authoritative attitudes. Similarly, Melby et al. (1993) concluded that authoritative and strict mother attitude weakens cognitive flexibility. Parents' attitudes are important in the formation of cognitive flexibility as from childhood and some cognitive structures are formed as a result of relations established with the family.

The findings reveal that the metacognitive learning strategies Identification levels of female teacher candidates are higher than those of male ones in planning strategies, observing strategies and the whole scale. However, the results of the studies by Memnun and Akkaya (2009); Ozsoy et al. (2010); Aydın and Coşkun (2011); Ozsoy and Günindi (2011) and Dilci and Seda (2012) show that gender does not affect metacognitive learning strategies use. Baykara (2011) found a result that is in favour of female teacher candidates in organization strategies. Tunca and Alkın-Sahin (2014) obtained the same result in planning, organization and supervising strategies. There are no scientific studies in literature claiming that metacognitive skills differ in terms of gender. In fact, the differences in the metacognitive awareness skills of individuals result from life style and are biological rather than gender since this skill develops as from $5^{\text {th }}-7^{\text {th }}$ ages and continues to improve throughout education life. Teaching is more effective than maturing in the acquisition of metacognitive skills (Subaşı, 1999)(cited from Gage and Berliner). A significant difference was found between the grades and cognitive flexibility levels of social studies teacher candidates. According to the findings, the cognitive flexibility levels of the teacher candidates at the $3^{\text {rd }}$ grade are higher than those studying at the $4^{\text {th }}$ grade. In addition, it can be concluded from the findings that there is no relation between the cognitive flexibility levels and general academic achievements of teacher candidates.

The results of the study indicate that metacognitive learning strategies Identification levels of social studies teacher candidates are high in general. Metacognitive learning strategies Identification levels of successful and very successful teacher candidates are found higher than those of the unsuccessful ones. Similarly, some studies have found that there is a positive relation between metacognitive learning strategies and academic achievement (Caliskan and Sunbul, 2011; Doğanay and Demir, 2011; Kaya, 2012; Demir, 2013; Kartal et al., 2013; Küçük Kılıç and Oncü, 2014; Ay and Uğurlu, 2016). On the other hand, Belet and Guven (2011) couldn't find a significant relation between the use of metacognitive learning strategies and academic achievements of teacher candidates. Teachers and teacher candidates must themselves be lifelong learners so that they can raise lifelong learners. They must follow and adapt to the latest developments and practice them in lessons (Açlkgöz, 2003). It would be useful and guiding to conduct similar studies on different study groups with different variables.

\section{References}

Açıkgöz, Ü.K., 2003. Active learning. Izmir: Educational World Publications.

Altunkol, F., 2011. Examining the relationship between cognitive flexibility and perceived stress levels of university students. Master's Thesis, Cukurova University, Adana, Turkey.

Ay, E. and N.B. Uğurlu, 2016. Examination of metacognitive learning strategies of social studies teacher candidates according to various variables. Turkish Studies International Periodical for the Languages, 11(3): 327-344.

Aydın, F. and M. Coşkun, 2011. Geography teacher candidates' metacognitive awareness levels: A case study from Turkey. Archives of Applied Science Research, 3(2): 551-557.

Bakircioglu, R., 2012. Dictionary of encyclopedic education and psychology. Ankara: Anı Publishing.

Baykara, K., 2011. A study on teacher candidates' perceptions of metacognitive learning strategies and teacher competence. Hacettepe University Journal of Education, 40(40): 80-92.

Belet, S.D. and M. Guven, 2011. Meta-cognitive strategy usage and epistemological beliefs of primary school teacher trainees. Educational Sciences: Theory and Practice, $11(1): 51-57$.

Bilgin, M., 2009. Some variables that predict cognitive flexibility. Journal of Cukurova University Faculty of Education, 3(36): 142-157.

Budak, S., 2009. Dictionary of psychology. Ankara: Bilim Pulishing.

Caliskan, M. and A.M. Sunbul, 2011. The effects of learning strategies instruction on metacognitive knowledge, using metacognitive skills and academic achievement (primary education sixth grade turkish course sample). Educational Sciences: Theory and Practice, $11(1): 148-153$.

Celikkaleli, Ö., 2014. The relationship between cognitive flexibility and academic, social and emotional competence beliefs in adolescents. Education and Science, 36(176): 347-354.

Cöğenli, A.G. and M. Güven, 2014. Validity and reliability of the metacognitive learning strategies scale. Dicle University Journal of Ziya Gökalp Education Faculty, 22: 283-297.

Demir, O., 2013. Examining the levels of cognitive awareness of teacher candidates during the course of study: A qualitative study. Hacettepe University Journal of Education, 44(44): 133-148.

Demirsöz, E.S., 2014. Metacognitive awareness and development. Trakya University Journal of Education Faculty, 4(2): 112-123.

Dennis, J.P. and W.J.S. Vander, 2010. The cognitive flexibility inventory: Instrument development and estimates of reliability and validity. Cognitive Therapy and Research, 34(3): 241-253.Available at: https://doi.org/10.1007/s 10608-009-9276-4.

Dilci, T. and K. Seda, 2012. Examination of metacognitive awareness levels of 4th and 5 th grade classroom teachers in terms of various variables. Süleyman Demirel University Faculty of Arts and Sciences Journal of Social Sciences, 2012(27): 247-267. 
Diril, A., 2011. To investigate the cognitive flexibility of high school students in terms of the relationship between sociodemographic variables and anger level and anger expression styles. Master's Thesis, Cukurova University, Adana, Turkey.

Dirkes, M.A., 1985. Metacognition: Students in charge of their thinking. Roeper Review, 8(2): 96-100.Available at: https://doi.org/10.1080/02783198509552944.

Doğanay, A. and O. Demir, 2011. Comparison of the levels of low and high academic prospective teachers' using cognitive awareness skills during the course of study. Educational Sciences in Theory and Practice, 11(4): 2021-2043.

Duman, B., 2011. Teaching principles and methods. Ankara: Anı Publishing.

Flavell, J.H., 1979. Metacognition and cognitive monitoring: A new area of cognitive-developmental inquiry. American Psychologist, 34(10): 906-911.Available at: https://doi.org/10.1037//0003-066x.34.10.906.

Hartman, H.J., 1998. Metacognition in teaching and learning: An introduction. Instructional Science, 26(1-2): 1-3.

Karasar, N., 2004. Scientific research method. Ankara: Nobel Publication Distribution.

Kartal, T., K. Kayacan and M. Selvi, 2013. Examination of teacher candidates' level of awareness about scientific attitudes and metacognitive learning strategies in terms of multiple variables. International Journal of Social Science, 6(1): 913-939.

Kaya, S., 2012. The effect of cognitive and metacognitive strategy activities on the prospective teachers' instructional design achievement and their use of cognitive and metacognitive strategies. PhD Thesis, Gazi University, Ankara, Turkey.

Küçük Kılıç, S. and E. Oncü, 2014. Metacognitive learning strategies and academic self-efficacy of physical education and sports students. Journal of Sport and Performance Research, 5(2): 13-22.

Martin, M.M. and C.M. Anderson, 1998. The cognitive flexibility scale: Three validity studies. Communication Reports, 11(1): 1-9.Available at: https://doi.org/10.1080/08934219809367680.

Martin, M.M. and R.B. Rubin, 1995. A new measure of cognitive flexibility. Psychological Reports, 76(2): 623-626.Available at: https://doi.org/10.2466/pro.1995.76.2.623.

Melby, J.N., R.D. Conger, K.J. Conger and F.O. Lorenz, 1993. Effects of parental behavior on tobacco use by young male adolescents. Journal of Marriage and Family, 55(2): 439-454.Available at: https://doi.org/10.2307/352814.

Memnun, D.S. and R. Akkaya, 2009. The levels of metacognitive awareness of primary teacher trainees. Procedia-Social and Behavioral Sciences, 1(1): 1919-1923.Available at: https://doi.org/10.1016/j.sbspro.2009.01.337.

Ozsoy, G., A. Cakiroglu and G.H. Kuruyer, 2010. Examination of metacognitive awareness levels of prospective classroom teachers in terms of some variables. 9th Grade Teacher Education Symposium, 9(1): 489-492.

Ozsoy, G. and Y. Günindi, 2011 . Metacognitive awareness levels of preschool teacher candidates. Elementary School Online, 10(2): 430-440.

Santrock, J.W., 2004. Educational psychology. New York: McGraw-Hill Higher Education.

Sapmaz, F. and T. Doğan, 2013. Assessment of cognitive flexibility: Validity and reliability studies of the Turkish version of the cognitive flexibility inventory. Ankara University Journal of the Faculty of Educational Sciences, 46(1): 143-161.Available at: https://doi.org/10.1501/egifak_0000001278.

Social Studies Curriculum, 2018. Available from http://mufredat.meb.gov.tr/Dosyalar/201812103847686SOSYAL $\% 20 B \%$ C4\%BOLG\%C4\%BoLER\%20\%C3\%96\%C4\%9ERET\%C4\%BoM\%20PROGRAMI\%20.pdf.

Subaşı, G., 1999. Cognitive learning approach, information processing theory. Journal of Vocational Education, 1(2): 27-36.

Tunca, N. and S. Alkın-Sahin, 2014. The relationship between teacher candidates' metacognitive learning strategies and academic selfefficacy beliefs. Anadolu Journal of Educational Sciences International, 4(1): 47-56.Available at: https://doi.org/10.18039/ajesi.89592.

Weinstein, C.E. and R.E. Mayer, 1986. The teaching of learning strategies, Wittock, M.C. (Ed.), Handbook of research on teaching. New York: Maccmillan Company. pp: 315-327.

Yazici, K., 2006. Social studies and reading skills. Gazi University Journal of the Faculty of Education, 26(1): 273-283. 